\title{
Paddy Crop Status in Tamil Nadu - A Statistical Analysis
}

\author{
S. Panchali Meena ${ }^{1 *}$ and K. Prabakaran ${ }^{2}$ \\ ${ }^{1}$ Agricultural College \& Research Institute, Madurai - TNAU Coimbatore, India \\ ${ }^{2}$ Agricultural College \& Research Institute, Madurai, India \\ *Corresponding author
}

\section{A B S T R A C T}

\begin{tabular}{|l|}
\hline Key w or d s \\
Paddy, Growth \\
$\begin{array}{l}\text { Rate, Instability and } \\
\text { Categorization }\end{array}$ \\
\hline Article Info \\
\hline $\begin{array}{l}\text { Accepted: } \\
\text { 22 January } 2018 \\
\text { Available Online: } \\
\text { 10 February } 2019\end{array}$ \\
\hline \hline
\end{tabular}

Agriculture is the backbone of Indian nation. Climate and technology are the parents for agriculture. Agriculture in Tamil Nadu is unique in its character, with respect to climate. It has varied agro-climatic zones which favors for the growth of various types of crops in the country. On the other hand it also depends on technology. Hence the present study was planned to analyses the performances of selected crops with respect to the technology. For this study, Paddy crop from Cereals is purposively selected. For this, five agro climatic zones and one district in each zone were purposively selected. Secondary data from the period 1990-1991 to 2009 -2010 were employed for the study. The result shows that the area under paddy shows negative growth rate with high instability index. Paddy production shows constant growth rate with high instability. Paddy productivity shows positive growth rate with low instability. Based on the agro climatic zone categorization, Cauvery Delta Zone - Thanjavur district, Western Zone - Erode .district and North Eastern Zone Villupuram district were considered as safe zone for paddy.

\section{Introduction}

Agriculture in Tamil Nadu has unique characteristics in agriculture with respect to climate. It is blessed with wide climatic regions thereby the growing of various types of crops are possible. While in other states some crops only grown because of the monotonic agro - climatic region. On the other hand it depends on technology. This study relates the climatic requirement and technology adopted by the crop.

The study focus on the vertical and horizontal movement of area, production and productivity of paddy crop in the selected districts. The vertical movement is the growth and the horizontal movement is instability. Based on the results of growth and instability, the selected zones and districts are classified as safe zone, moderately safe zone and poorly safe zone. This study was carried out with following objectives

To Study the growth of area, production and productivity of Paddy crop.

To measure the extent of variation in area, production and productivity of Paddy crop.

To categorize the different agro climatic zone based on the growth and instability. 


\section{Materials and Methods}

\section{Selection of crop and study area}

Paddy crop was purposively selected for the study. It was the major crop cultivated in Tamil Nadu. Among the seven agro climatic zones, five agro climatic zones and one district in each zone was purposively selected viz., Thanjavur district from Cauvery Delta Zone, Villupuram district from North Eastern Zone, Salem district from North Western Zone, Erode district from Western Zone and Virudhu nagar district from Southern Zone. The study covered the period from 1990 - 1991 to 2009 2010. The entire period was sub divided into two sub periods based on the introduction of System of Rice Intensification (SRI).

Pre Introduction Period (1990 - 2000)

Post Introduction Period (2000 - 2010)

\section{Estimation of growth rate}

An exponential function of the form

Where,

$$
\begin{aligned}
& Y=A B^{t} \\
& \log Y=\log A+t \log B
\end{aligned}
$$

$\mathrm{Y}=$ Area $/$ Production / Productivity

$\mathrm{A}=$ Constant

$\mathrm{B}=$ Regression Coefficient, and

$\mathrm{t}=$ Time (in years)

Compound growth rate $(\mathrm{CGR})=($ Antilog of $\mathrm{B}-$ 1) $\mathrm{x} 100$

\section{Instability analysis}

Paddy area, production and productivity Variation was estimated using Cuddy-Della Valle index (CDVI) and categorized in Table 1.

\section{Cuddy-Della Valle index (CDVI)}

$$
I=C V^{*} \sqrt{ }\left(1-R^{2}\right)
$$

Where
I is the instability index, $\mathrm{CV}$ is the coefficient of variation and $R^{2}$ is the coefficient of determination

$$
\mathrm{CV}=\frac{\sigma}{\mu} * 100
$$

$\sigma=$ Standard deviation and $\mu=$ Mean

Table.1 Categorization of CDVI Value

\begin{tabular}{|r|l|l|}
\hline S.No & CDVI Value & \multicolumn{1}{|c|}{ Category } \\
\hline $\mathbf{1 .}$ & $0-15$ & Low \\
\hline $\mathbf{2 .}$ & $15-30$ & Moderate \\
\hline $\mathbf{3 .}$ & Above 30 & High \\
\hline
\end{tabular}

\section{Results and Discussion}

\section{Villupuram District}

The growth rate is positive for area, production and productivity for both the sub periods and the overall period. The compound growth rate of paddy in Villupuram District during the pre-introduction period for area is $5.48 \%$ per annum, for production $2.30 \%$ per annum and for productivity $0.89 \%$ per annum. In case of post introduction period for area is $2.59 \%$ per annum, for production $2.04 \%$ per annum and for productivity $3.73 \%$ per annum. In case of overall period the area increased $0.5811 \%$ per annum, production increased $10.572 \%$ per annum and the productivity increased $1.5929 \%$ per annum. While comparing two sub period growth rates, the area declining in the post introduction period while comparing the pre introduction period but the production is maintained as a same level by the increase of productivity in post introduction period.

\section{Growth rate of paddy crop in the selected districts}

The results of compound growth rate for paddy crop area, production and productivity in the selected districts of Tamil Nadu are presented in the following Table 2 . 
Table. 2 Growth rate of paddy crop area, production and productivity in the selected districts

\begin{tabular}{|c|c|c|c|c|}
\hline \multirow[b]{2}{*}{ S.No } & \multirow[b]{2}{*}{ Period } & \multicolumn{3}{|c|}{ Compound Growth Rate (\%) } \\
\hline & & Area & Production & Productivity \\
\hline \multicolumn{5}{|c|}{ Villupuram } \\
\hline 1. & Pre Introduction Period (1990-2000) & 5.484 & 2.307 & 0.895 \\
\hline 2. & Post Introduction Period (2000-2010) & 2.59 & 2.048 & 3.732 \\
\hline 3. & Overall Period (1990-2010) & 0.5811 & 10.572 & 1.5929 \\
\hline \multicolumn{5}{|l|}{ Salem } \\
\hline 1. & Pre Introduction Period (1990-2000) & 6.070 & 2.410 & 1.148 \\
\hline 2. & Post Introduction Period (2000-2010) & -1.771 & 2.159 & 2.395 \\
\hline 3. & Overall Period (1990-2010) & -1.779 & -2.303 & 0.552 \\
\hline \multicolumn{5}{|l|}{ Erode } \\
\hline 1. & Pre Introduction Period (1990-2000) & -2.1585 & -0.381 & 1.816 \\
\hline 2. & Post Introduction Period (2000-2010) & 4.411 & 4.369 & 0.0397 \\
\hline 3. & Overall Period (1990-2010) & 1.9515 & 5.207 & 0.3940 \\
\hline \multicolumn{5}{|c|}{ Thanjavur } \\
\hline 1. & Pre Introduction Period (1990-2000) & 1.0520 & 0.8759 & -0.1742 \\
\hline 2. & Post Introduction Period (2000-2010) & -0.5038 & 1.593 & 2.0998 \\
\hline 3. & Overall Period (1990-2010) & -1.569 & 0.027 & 0.7048 \\
\hline \multicolumn{5}{|c|}{ Virudhu Nagar } \\
\hline 1. & Pre Introduction Period (1992-1993) & 0.7299 & 2.2039 & 1.456 \\
\hline 2. & Post Introduction Period (2000-2010) & 0.7871 & 2.5212 & 1.772 \\
\hline 3. & Overall Period (1990-2010) & -0.008 & 0.4828 & 0.8486 \\
\hline
\end{tabular}

\section{Salem District}

The growth rate of area, production and productivity is positive except the growth rate of area in post introduction period and over all period and the growth rate of production in overall period is negative. The compound growth rate of paddy in Salem District during the pre-introduction period for area is $6.07 \%$ per annum, for production $2.41 \%$ per annum and for productivity $1.14 \%$ per annum. In case of post introduction period for area is $-1.77 \%$ per annum, for production $2.15 \%$ per annum and for productivity $2.39 \%$ per annum. In overall period the area declined at a rate of $1.779 \%$ per annum, production declined at the rate of $2.303 \%$ per annum and the productivity increased at the rate of $0.552 \%$ per annum. While comparing two sub period growth rates, the area declining in the post introduction period but the production is maintained as a constant percent by the increasing in productivity in post introduction period. 


\section{Erode District}

The growth rate of area, production and productivity is positive except the growth rate of area and production in pre introduction period is negative. The compound growth rate of paddy in Erode District during the preintroduction period for area is $-2.15 \%$ per annum, for production $-0.38 \%$ per annum and for productivity $1.81 \%$ per annum. In case of post introduction period for area is $4.41 \%$ per annum, for production $4.36 \%$ per annum and for productivity $0.039 \%$ per annum. In overall period the area increased at the rate of $1.951 \%$ per annum, production increased at the rate of $5.207 \%$ per annum and the productivity increased at the rate of $0.3940 \%$ per annum. While comparing two sub period growth rates, the area and production increasing in the post introduction period while comparing to the pre introduction period.

\section{Thanjavur District}

The growth rate of area, production and productivity is positive except the growth rate of area in post introduction period and over all period and the growth rate of productivity in pre introduction period is negative. The compound growth rate of paddy in Thanjavur District during the pre-introduction period for area is $1.05 \%$ per annum, for production $0.87 \%$ per annum and for productivity $-0.17 \%$ per annum. In case of post introduction period for area is $-0.50 \%$ per annum, for production $1.59 \%$ per annum and for productivity $2.09 \%$ per annum. In overall period the area declined at the rate of $1.569 \%$ per annum, production increased at the rate of $0.027 \%$ per annum and the productivity increased at the rate of $0.7048 \%$ per annum. While comparing two sub periods growth rates, the area declining in the post introduction period the production and productivity were increasing in post introduction period.

\section{Virudhu nagar District}

The growth rate of area, production and productivity is positive except the growth rate of area in overall period is negative. The compound growth rate of paddy in Virudhu nagar District during the pre-introduction period for area is $0.72 \%$ per annum, for production $2.20 \%$ per annum and for productivity $1.45 \%$ per annum. In case of post introduction period for area is $0.78 \%$ per annum, for production $2.52 \%$ per annum and for productivity $1.77 \%$ per annum. In overall period the area declined at a rate of $0.008 \%$ per annum, production increased at the rate of $0.4828 \%$ per annum and the productivity increased at the rate of $0.8486 \%$ per annum. While comparing two sub period growth rates, the area is nearly same in both the periods. The production is increased due to the increase in productivity in post introduction period.

In North Eastern Zone - Villupuram District, North Western Zone - Salem District and Cauvery Delta zone - Thanjavur District while comparing two sub period growth rates of area under paddy, declining in the post introduction period while comparing the pre introduction period but the paddy production is maintained as a constant percent by the increasing in paddy productivity.

In Western Zone - Erode District while comparing two sub period growth rates, the area under paddy increasing in the post introduction period while comparing the pre introduction period and the paddy production is increased but the paddy productivity decreased. The increased in paddy production due to area expansion in Erode District. In Southern Zone - Virudhu nagar District while comparing two sub period growth rates of area under paddy is nearly same in both the periods. The paddy production is increased due to the increasing in productivity.

Among the various zone, Western zone Erode - 
District has recorded highest growth rate in area under paddy. In paddy production and productivity the North Eastern zone Villupuram District has highest growth rate in overall period. Similar results were obtained by Shivkant et al. (2016) in his studies on Effect of yield, quality attributes and cost of rice (Oryza sativa L.) variety under System of rice intensification (SRI) Organic \& Conventional methods of rice cultivation. He found that advantage of SRI method in case of reduction in cost of cultivation, higher yields obtained per acre (higher productivity effect) and lesser duration for harvesting the crop.

Therefore, he concluded that the SRI method of cultivation is advantageous to the paddy farmers as compared to Conventional method.

\section{Instability Index of Paddy Crop in the Selected Districts}

\section{Villupuram District}

In pre introduction period area has low instability while medium instability in post introduction period. In case of production both the periods have medium instability. In case of productivity the instability is high in pre introduction period and over all period. The productivity instability is low in case of post introduction period. In overall period the area instability is medium and the production and productivity instability is high.

\section{Salem District}

It was observed that the area, production and productivity instability is low in pre introduction period. In post introduction period area and production instability is high, where the productivity instability is low. In overall period the area and production instability is high and the productivity instability is low. The area instability is low in pre introduction period when compared to post introduction period and over all period.
Similarly production shows low instability in pre introduction period when compared to post introduction period and over all period. In case of productivity all the period have low instability.

\section{Erode District}

It was observed that the area, production and productivity instability is low in pre introduction period. In post introduction period area and production instability is high where the productivity instability is low. In overall period the area and production instability is medium and the productivity instability is low.

The area instability is low in pre introduction period when compared to post introduction period (high instability) and over all period (medium instability). In production low instability in pre introduction period when compared to post introduction period (high instability) and over all period (medium instability). In case of productivity all the period have low instability.

\section{Thanjavur District}

It was observed that the area instability is low in all the periods. In case of production pre introduction and the overall period shows high instability where in post introduction period shows medium instability.

In case of productivity the instability is high in pre introduction period and overall period and the post introduction period shows medium instability.

In pre introduction and overall period area instability is low but the production and productivity instability is high. In post introduction period the area instability is low and the production and productivity are medium. The results of instability analysis for 
paddy crop area, production and productivity presented in the following Table 3. in the selected districts of Tamil Nadu are

Table.3 Instability index of paddy crop area, production and productivity in the selected districts

\begin{tabular}{|c|c|c|c|c|}
\hline \multirow[b]{2}{*}{ S.No } & \multirow[b]{2}{*}{ Period } & \multicolumn{3}{|c|}{ Cuddy Della Valle Index (\%) } \\
\hline & & Area & Production & Productivity \\
\hline \multicolumn{5}{|c|}{ Villupuram } \\
\hline 1. & Pre Introduction Period (1990-2000) & 12.122 & 28.648 & 34.914 \\
\hline 2. & Post Introduction Period (2000-2010) & 22.984 & 25.428 & 5.695 \\
\hline 3. & Overall Period (1990-2010) & 21.052 & 42.232 & 33.068 \\
\hline \multicolumn{5}{|c|}{ Salem } \\
\hline 1. & Pre Introduction Period (1990-2000) & 15.000 & 13.515 & 4.708 \\
\hline 2. & Post Introduction Period (2000-2010) & 39.944 & 47.600 & 11.712 \\
\hline 3. & Overall Period (1990-2010) & 31.280 & 38.345 & 10.584 \\
\hline \multicolumn{5}{|l|}{ Erode } \\
\hline 1. & Pre Introduction Period (1990-2000) & 6.574 & 2.350 & 5.228 \\
\hline 2. & Post Introduction Period (2000-2010) & 45.101 & 45.226 & 8.268 \\
\hline 3. & Overall Period (1990-2010) & 25.378 & 25.899 & 7.431 \\
\hline \multicolumn{5}{|c|}{ Thanjavur } \\
\hline 1. & Pre Introduction Period (1990-2000) & 5.102 & 38.935 & 41.374 \\
\hline 2. & Post Introduction Period (2000-2010) & 13.247 & 25.171 & 18.093 \\
\hline 3. & Overall Period (1990-2010) & 10.195 & 32.595 & 31.104 \\
\hline \multicolumn{5}{|c|}{ Virudhu Nagar } \\
\hline 1. & Pre Introduction Period (1990-2000) & 22.845 & 44.321 & 32.359 \\
\hline 2. & Post Introduction Period (2000-2010) & 9.650 & 32.083 & 24.745 \\
\hline 3. & Overall Period (1990-2010) & 18.132 & 39.999 & 28.692 \\
\hline
\end{tabular}




\section{Virudhu nagar District}

It was observed that the area instability is medium in pre introduction period while the production and productivity instability is high. In post introduction period area instability is low, the productivity is medium and production instability is high. In overall period the area and productivity instability is medium and the production instability is high. The area instability is low in post introduction period when compared to pre introduction period and over all period (medium instability). In production, the instability is high in both periods and over all period. In productivity pre introduction period has high instability when compared to post introduction period and over all period (medium instability).

In North Eastern Zone - Villupuram District, North Western Zone - Salem District, Cauvery Delta zone - Thanjavur District and Western Zone - Erode District while comparing the instability for two sub periods the area instability is low in case of pre introduction period when compared to post introduction period. In case of Southern Zone - Virudhu nagar District the area instability is low in post introduction period when compared to pre introduction period. In case of production and productivity in North Eastern Zone - Villupuram District, Cauvery Delta zone - Thanjavur District and Southern Zone - Virudhu nagar District the pre introduction period have high instability when compared to post introduction period. In other zones the pre introduction period have low instability when compared to the post introduction period.

Among the various zone high instability in area were recorded in Erode District Post introduction period and low instability were recorded in Thanjavur District Pre introduction period. In production the high instability were recorded in Salem District Post introduction period and low instability in Erode District Pre introduction period. In productivity observed the high instability were recorded in Thanjavur District Pre introduction period and low instability in Salem District Pre introduction period.

\section{Categorization of Different Agro Climatic Zones}

The different agro climatic zones are categorized based on growth rate and instability index of overall study period.

\section{Categorization of different agro climatic} zones according to paddy area

Table 4 reveals that in paddy area, the North Eastern Zone - Villupuram district and Western Zone - Erode district are safe with positive growth and medium instability. Cauvery Delta Zone - Thanjavur district is moderately safe with negative growth and low instability. In case of Southern Zone Virudhu nagar, the area has a poor safe with negative growth and medium instability. In case of North Western Zone - Salem district has poor safe with low growth and high instability.

Table.4 Categorization of different agro climatic zones according to paddy area

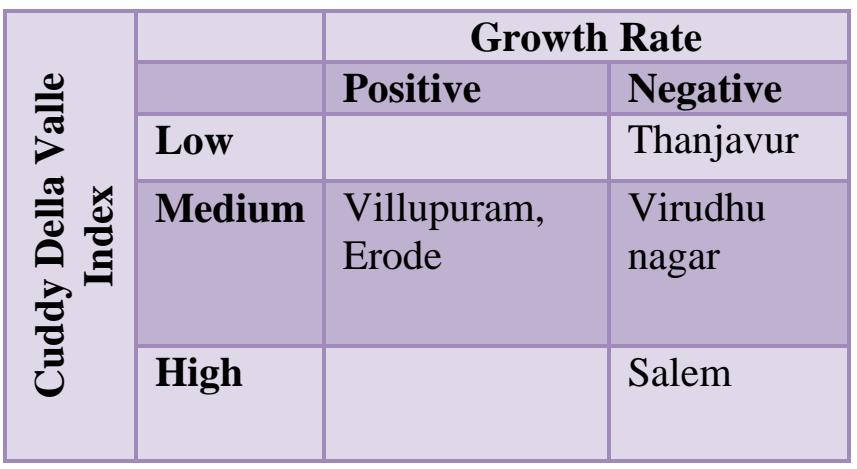


Categorization of different agro climatic zones according to paddy production

Table 5 reveals that in paddy production, Western Zone - Erode district is safe with positive growth and medium instability. North Eastern Zone - Villupuram district, Cauvery Delta Zone - Thanjavur and Southern Zone Virudhu nagar district are moderately safe with positive growth and high instability. In case of North Western Zone - Salem has poor safe with low growth and high instability.

Table.5 Categorization of different agro climatic zones according to paddy production

\begin{tabular}{|c|c|c|c|}
\hline \multirow{5}{*}{ 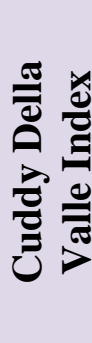 } & & \multicolumn{2}{|c|}{ Growth Rate } \\
\hline & & Positive & Negative \\
\hline & Low & & \\
\hline & Medium & Erode & \\
\hline & High & $\begin{array}{l}\text { Villupuram, } \\
\text { Thanjavur, } \\
\text { Virudhu nagar }\end{array}$ & Salem \\
\hline
\end{tabular}

Categorization of different agro climatic zones according to paddy productivity

Table 6 reveals that in case of paddy productivity all the zones are safe with respect to growth rate. According to the instability, Western Zone - Erode district and North Western Zone - Salem are safe with positive growth and low instability. Southern Zone Virudhu nagar district moderately safe with positive growth and medium instability. North Eastern Zone - Villupuram district, Cauvery Delta Zone - Thanjavur district are poor safe with positive growth and high instability.

Area under paddy declined in the post introduction period in all the districts except Erode district. Paddy production was maintained constantly in all the districts except Erode district. Paddy productivity was increased in all the districts except Erode district. In paddy, area instability was high in post introduction period when compared to pre introduction period in the selected district except in Virudhu nagar district. Production instability was decreased in post introduction period when compared to pre introduction period except in Salem and Erode district. In productivity instability was low in all the selected districts except in Salem and Erode district. For paddy area, North Eastern Zone Villupuram district, Western Zone - Erode district and Cauvery Delta Zone - Thanjavur districts were considered as safe zone. For paddy production, Western Zone - Erode district, North Eastern Zone - Villupuram district and Cauvery Delta Zone - Thanjavur districts were considered as safe zone. For productivity North Western Zone - Salem district, Western Zone - Erode district and Southern Zone - Virudhu nagar districts were considered as safe zone.

\section{Table.6 Categorization of different agro climatic zones according to paddy productivity}

\begin{tabular}{|c|c|c|c|}
\hline \multirow{5}{*}{ 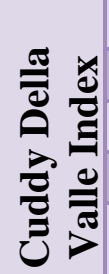 } & & \multicolumn{2}{|c|}{ Growth Rate } \\
\hline & & Positive & Negative \\
\hline & Low & Salem, Erode & \\
\hline & Medium & Virudhu nagar & \\
\hline & High & $\begin{array}{l}\text { Villupuram, } \\
\text { Thanjavur }\end{array}$ & \\
\hline
\end{tabular}

\section{References}

Abdullah, M. Jia Li, S. Ghazanfar and I. Khan. (2015). European Journal of Economic Studies, 11 (1): 4-15.

Amarender and Devi raj (2006), Growth and Instability in Chickpea Production in India: A State Level Analysis. Agricultural Situation in India, 14(6): 230-245.

Dhakre, D. S. and D. Bhattacharya. Growth and Instability Analysis of Vegetables in West Bengal, India. International 
Journal of Bio-resource and Stress Management 4(3): 456-459.

Shivkant S., Joanna Bloese and Tapan Ray (2016) Effect of yield, quality attributes and cost of rice (Oryza sativa L.) variety under System of rice intensification (SRI) Organic \& Conventional methods of rice cultivation, International Journal of Scientific and Research Publications, 6(6).

\section{How to cite this article:}

Panchali Meena, S. and Prabakaran, K. 2019. Paddy Crop Status in Tamil Nadu - A Statistical Analysis. Int.J.Curr.Microbiol.App.Sci. 8(02): 3316-3324.

doi: https://doi.org/10.20546/ijcmas.2019.802.386 